\title{
The Use of Biology Textbook based on Collaborative Learning Model to Improve Scientific Literacy Skill
}

\author{
Virlya Citra Dewi ${ }^{1}$, Endang Susantini ${ }^{2}$, Sri Poedjiastoeti ${ }^{3}$ \\ 1,2,3Universitas Negeri Surabaya, Surabaya, Indonesia
}

\begin{tabular}{|c|c|}
\hline (A) Check for updates open access (c) (1) (2) & DOI : https://doi.org/10.46245/ijorer.v2i4.130 \\
\hline Sections Info & ABSTRACT \\
\hline Article history: & \multirow{11}{*}{$\begin{array}{l}\text { Scientific literacy skills are important skills taught to prepare students for the } \\
21 \text {-st century learning era. Textbook based on collaborative learning model } \\
\text { can be an alternative to improving students' scientific literacy skills. The } \\
\text { purpose of the study was to describe scientific literacy skills and student } \\
\text { responses through the use of biology textbook based on collaborative learning } \\
\text { model. The type of research used is descriptive quantitative research with one } \\
\text { group pretest-posttest research design. The instruments used are scientific } \\
\text { literacy skills tests and response questionnaire sheets. The N-gain score, a } \\
\text { paired sample t-test, and the results of the students' responses were used to } \\
\text { analyze the data. The results showed that the value of the science literacy } \\
\text { skills test increased with an N gain of } 0.67 \text {, sig } 0.05 \text {, and } 95 \% \text { of students } \\
\text { responded positively. These results indicate that textbook based on } \\
\text { collaborative learning model is effectively used to train students' scientific } \\
\text { literacy skills and can be tested widely. }\end{array}$} \\
\hline Submitted: June 30, 2021 & \\
\hline Final Revised: July 10, 2021 & \\
\hline & \\
\hline Published Online: July 31, 2021 & \\
\hline Keywords: & \\
\hline Biology textbook & \\
\hline 21"st Century learning & \\
\hline Collaborative learning & \\
\hline Scientific literacy skill & \\
\hline 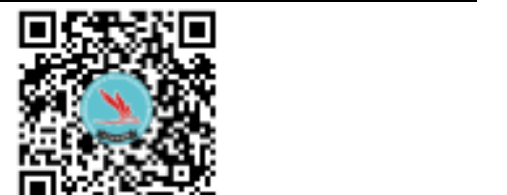 & \\
\hline
\end{tabular}

\section{INTRODUCTION}

Science is a human effort to understand the universe through precise observations of the target, as well as using procedures, and explained by reasoning so as to produce a conclusion (Susanto, 2013). The provision of quality science education is expected to be able to equip students to face global problems. This is because, in science learning, especially through scientific literacy, students are trained to solve problems (Afriana et al., 2016). Scientific literacy is a competency that must be possessed by students by involving scientific issues, scientific ideas and being someone who thinks critically (OECD, 2016). Scientific literacy is the ability to interact with various basic values of science, so that it can be used in solving problems in the current era of technological progress (Laugksch, 2017; Saraswati et al., 2021). Some areas of science literacy were separated, such as the environment, climate, and earth (Suryani and Hariyono, 2021). Scientific literacy views the importance of thinking and acting skills that involve mastering thinking and using scientific thinking in recognizing and addressing social issues. Scientific literacy is important for students to understand the environment, health, the economy, modern society, and technology.

The results of a survey conducted by the Program for International Student Assessment (PISA), show that Indonesian students have low scientific literacy skills, which are ranked 69th out of 76 countries (OECD, 2016). Other studies have also proven the low scientific literacy skills of Indonesian students (Merta et al., 2020; Robbia and Fuadi, 2020; Diana et al., 2015). This should reflect educators' ability to create meaningful learning while practicing scientific literacy skills. Student must be trained in this skill more effectively because it can meet all of the demands of $21^{\text {st }}$ century 
learning.The $21^{\text {st }}$ century learning expects students to learn and actively communicate and emphasizes the importance of working together and collaboration to solve problems. Students have the opportunity to socialize with friends and be actively involved with the teacher as a mentor or facilitator. Textbooks are one of the supporters of success in achieving learning objectives and to find out what the role of quality textbooks is in increasing the effectiveness of learning. Textbooks are a form of written teaching that students can use as a source for learning. In developing teaching materials that are correct and suiTable for the needs of the learning community, it is the best effort to improve learning outcomes (Hera et al., 2014).

One of the teaching materials that can be used is textbooks. Textbooks as teaching materials have an important role in learning, including making learning interesting, practical, seeming easier and more meaningful and even being able to develop attitudes and values (Saglam, 2011; Zhang et al., 2013). A good textbook must meet theoretical feasibility in terms of content, presentation and language (BSNP, 2014). The preparation of textbooks must be in accordance with the 2013 curriculum, which is a studentcentered learning process.

In addition to textbooks, learning models must provide a lot of experience for students (Millah et al., 2012). A good textbook is for a learning activity in the textbook by forming a study group with a collaborative learning model. Students must be taught how to collaborate so that the souls of mutual responsibility, honesty, respect, appreciation, sympathy, and openness can be nurtured (Apriono, 2013).

Previous research has also proven the effectiveness of collaborative learning-based learning (Voorn and Kommers, 2013; Al Omoush, 2018; Weinberger et al., 2007; Ansari and Khan, 2020; Le et al., 2017; Dooley and Bamford, 2018; Chen and Kuo, 2019). Leeuwen and Janssen (2019) said that collaboration supports the student's learning process. The findings of Laily and Rachmadiarti's (2019) research show that scientific literacy can be taught through textbook based on collaborative learning model on biodiversity materials, because the material is relevant to students' lives.This also applies to ecosystem materials, materials that have a broad scope, close to the student environment (Anfa et al., 2016).

Ecosystem materials can be taught through the environment around students, so students are trained to observe phenomena, evaluate and design scientific investigations and interpret data and evidence scientifically. Several sub-chapters on ecosystem materials can also be taught through practical activities that require students to analyze and evaluate data to draw conclusions. For example, in the biogeochemical cycle subsection, students are asked to ensure the importance of the presence of plants in helping the biogeochemical cycle through practical activities. The practicum activities in question can be carried out in collaborative learning-based learning, where students collaborate with each other to solve problems. Based on this background, research to prove students' scientific literacy skills can be improved through textbook based on collaborative learning model on ecosystem materials needs to be done.

\section{RESEARCH METHOD}

\section{General Background}

The purpose of the study was to describe scientific literacy skills and student responses through the use of biology textbook based on collaborative learning model. The research procedures in Figure 1. 


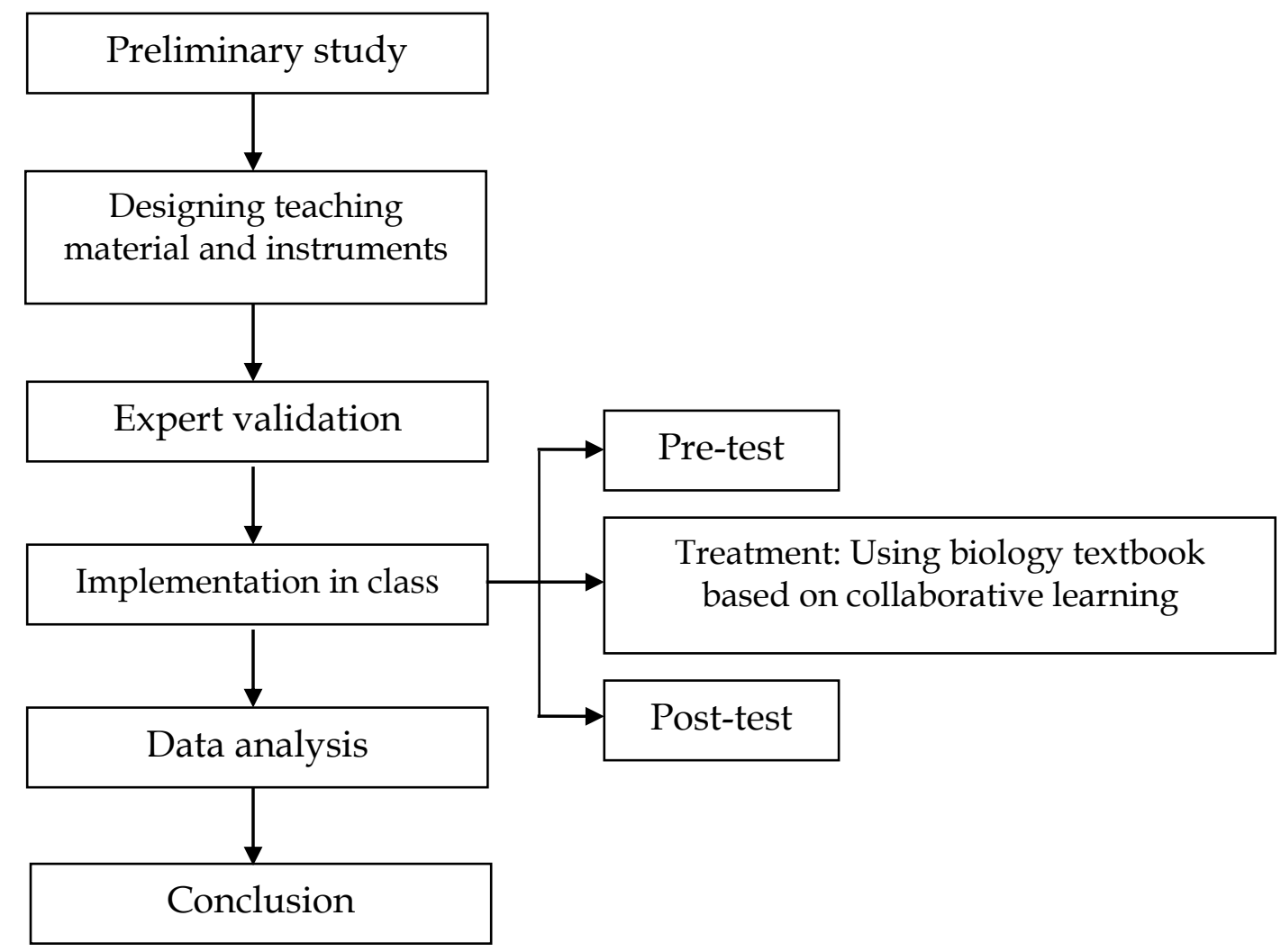

Figure 1. Diagram of research procedures.

According to Figure 1, the research begins with a preliminary study in which there is a gap between facts and expectations in Senior high school 1 Ngunut, and the scientific literacy skill of students is still considered to be less than optimal, necessitating alternative solutions through biology textbooks based on collaborative learning model. Researchers created learning devices and instruments based on these gaps in order to measure their improved results. The devices and instruments that have been created are next validated by expert until they are certified valid and practical to use (data has been included in another article). The learning devices and instruments are subsequently applied in grade X Senior high school 1 Ngunut when they have been certified legitimate and viable to use. The method used in this research is a single group pretest-posttest design and a descriptive method. The research methodology includes an initial observational test, followed by a treatment utilizing the textbook, and a final observational test of scientific literacy skills and student responses. Model scheme for one group pre-test and post-test (Sugiyono, 2011).

\section{$\mathrm{O}_{1 \times} \mathrm{O}_{2}$}

\section{Description:}

$\mathrm{O} 1=$ Pretest to see students' initial conception of the ecosystem concept before using textbook-based collaborative learning.

$\mathrm{X}=$ Treatment, namely applying textbooks based on collaborative learning.

O2 = Posttest to see students' conceptions of the ecosystem concept after using textbook-based collaborative learning. 


\section{Sample}

Test 1 of the application of textbooks was carried out on class $X$ students of Senior High School 1 Ngunut with a sample of 15 students in December of the 2019/2020 school year. Data collection was obtained from test results and student responses by using collaborative learning-based textbooks. The previously applied textbooks have obtained valid results and have been revised according to the validator's suggestions.

\section{Instrument and Procedures}

The types of instruments used in this study were tests of scientific literacy skills and student response questionnaires. The scientific literacy skills test is prepared by taking into account the indicators of scientific literacy skills, including (a) observing a phenomenon; (b) evaluating and designing scientific investigations; and (c) interpreting data and evidence scientifically. The test is in the form of essay questions totaling 12 questions. Student response sheets are in the form of 15 questions consisting of aspects of presenting content, physics and language in collaborative learning-based textbooks.

\section{Data Analysis}

Improvement in students' scientific literacy skills was obtained from the results of the students' pretest and posttest, which were then analyzed based on $\mathrm{N}$ gain (Hake, 2014). The $\mathrm{N}$ gain formula is as follows:

$$
<\mathbf{g}>=\frac{\%<S f>-\%<S i>}{\%<S \text { maks }>-\%<S i>} \times 100 \%
$$

Description:

$\mathrm{S}_{\mathrm{t}} \quad=$ final score (posttest)

$\mathrm{S}_{\mathrm{i}} \quad=$ initial score (pretest)

$\mathrm{S}_{\max } \quad=$ maximum score that can be achieved.

The $\mathrm{N}$ gain value obtained can then be categorized as low, medium or high according to the following criteria:

Table 1. Interpretation of scientific literacy (N-gain score).

\begin{tabular}{cc}
\hline Normalized N-Gain Range & Criteria of N-Gain \\
\hline $\mathrm{g}<0,30$ & Low \\
$0,30 \leq \mathrm{g} \leq 0,7$ & medium \\
$\mathrm{g}>0,70$ & High \\
\hline
\end{tabular}

The data from the pretest and posttest were also analyzed using normality test, homogeneity test and paired sample t-test. The data normality test was conducted to determine whether the data from each group was normally distributed or not. The normality test of this data must be carried out before the statistical hypothesis is determined. The homogeneity of the data can also be analyzed after conducting the homogeneity test, then the decision making is adjusted to the results of the paired sample t-test using SPSS 23. 


\section{RESULTS AND DISCUSSION}

Students' Science Literacy Skills

The Improvement of students' scientific literacy skills can be seen from the average scores of students' pretest and posttest scores, because the analysis of learning outcomes data uses the degree of increase in N-Gain. The results of the analysis of student learning outcomes and scientific literacy skills are presented in Table 2.

Table 2. Interpretation of scientific literacy (gain score)

\begin{tabular}{|c|c|c|c|c|c|c|c|}
\hline No & $\begin{array}{l}\text { Student's } \\
\text { Name }\end{array}$ & Pre-Test & Criteria & Post-Test & Criteria & $\begin{array}{c}\mathbf{N} \\
\text { Gain }\end{array}$ & Category \\
\hline 1 & $\mathrm{~A}$ & 64.58 & Fair & 85.42 & Very Good & 0.59 & Medium \\
\hline 2 & B & 60.42 & Fair & 89.58 & Very Good & 0.74 & High \\
\hline 3 & $\mathrm{C}$ & 79.17 & Good & 93.75 & Very Good & 0.70 & High \\
\hline 4 & $\mathrm{D}$ & 64.58 & Fair & 89.58 & Very Good & 0.71 & High \\
\hline 5 & $\mathrm{E}$ & 60.42 & Fair & 91.67 & Very Good & 0.79 & High \\
\hline 6 & $\mathrm{~F}$ & 58.33 & Fair & 87.50 & Very Good & 0.70 & High \\
\hline 7 & G & 70.83 & Good & 91.67 & Very Good & 0.71 & High \\
\hline 8 & $\mathrm{H}$ & 75.00 & Good & 87.50 & Very Good & 0.50 & Medium \\
\hline 9 & I & 64.58 & Fair & 89.58 & Very Good & 0.71 & High \\
\hline 10 & $\mathrm{~J}$ & 70.83 & Good & 87.50 & Very Good & 0.57 & Medium \\
\hline 11 & K & 56.25 & Fair & 79.17 & Good & 0.52 & Medium \\
\hline 12 & $\mathrm{~L}$ & 58.33 & Fair & 87.50 & Very Good & 0.70 & High \\
\hline 13 & $\mathrm{M}$ & 64.58 & Fair & 87.50 & Very Good & 0.65 & Medium \\
\hline 14 & $\mathrm{~N}$ & 68.75 & Good & 93.75 & Very Good & 0.80 & High \\
\hline \multirow[t]{2}{*}{15} & $\mathrm{~K}$ & 58.33 & Fair & 83.33 & Good & 0.60 & Medium \\
\hline & Average & 65.00 & Fair & 88.47 & Very Good & 0.67 & Medium \\
\hline
\end{tabular}

Criteria:

$\begin{array}{lll}\text { Very good } & =85<X \leq 100 \\ \text { Good } & =70<X \leq 85 \\ \text { Fair } & =55<X \leq 70 \\ \text { Poor } & =0<X \leq 55\end{array}$

Based on the N-Gain analysis, it can be seen that there is an increase after the implementation of learning with collaborative learning-based textbooks. The increase in the high category occurred among 9 students, while 6 students experienced an increase in the medium category. This means that collaborative learning-based textbooks used in learning can train and improve scientific literacy skills.

The medium category in the value of $\mathrm{N}$ gain in scientific literacy skills is caused by a number of factors, including the results of the analysis during the pretest activity and interviews with teachers and student representatives, which revealed that students were not used to working on the form of scientific literacy skills. Science literacy skill questions do require reasoning and the application of science to understand the questions. Therefore, students who are accustomed to working on multiple choice questions with easy categories will have difficulty when faced with essay questions. Gunawan (2016), in his research, explains that if someone is used to solving story-form problems, they will automatically know what is known and what is asked in each question, according to their habits. The pretest work carried out at home was also analyzed as the cause of the high pretest score, due to the lack of teacher supervision of 
the work. Thus, the difference between the students' pretest and posttest was not too high.

The results of the students' pretest and posttest were analyzed using SPSS to determine the effect of using collaborative learning in training students' scientific literacy skills. These results can be seen in Table 3 .

Table 3. The Result of Normality test, Homogeny test and Paired sample t-test.

\begin{tabular}{|c|c|c|}
\hline \multirow{2}{*}{ Statistic Parameter } & \multicolumn{2}{|c|}{ Score } \\
\hline & Pre-test & Post-test \\
\hline Mean & 64.99 & 88.33 \\
\hline Normality test & 0.25 & 0.26 \\
\hline Homogeneity test & \multicolumn{2}{|c|}{0.052} \\
\hline Paired sample t-test & \multicolumn{2}{|c|}{0.000} \\
\hline
\end{tabular}

According to the Table 3, the value of the sig. normality test is greater than 0.05 , indicating that the data is normally distributed. A sig. value of $0.052>0.05$ was obtained in the homogeneity test, indicating that the data was homogeneous and could be used for statistical tests. The statistical paired sample t-test yielded a sign of 0.000 0.05. As a result, there is an effect of using collaborative learning tools on improving students' scientific literacy. Laal \& Laal (2012) explain that collaborative learning proposes a way of dealing with people that emphasizes individual abilities and contributions. This learning is able to increase the flow of information, cooperation, support, and a sense of commitment to group goals. Many studies have explored the importance of a sense of community and collaborative learning activities in a learning environment (Chatterjee \& Correia, 2019).

Collaborative learning facilitates reflection, diversifies understanding and stimulates critical and higher-order thinking skills, as well as improves student performance (Fakomogbon \& Bolaji, 2017; Saqr et al., 2018). Social constructivists see humans as social beings who grow by developing knowledge and skills through interactions with different communities. They assume that learning is a social byproduct of conversation and negotiation with peers and that learners acquire knowledge by participating in relevant social activities or working collaboratively in groups (Liu \& Matthews, 2005; Siemens, 2008). Through collaborative learning, students are encouraged to be actively involved in learning. Collaborative learning promotes student collaboration in small groups (two to five students) to optimize their own and each other's learning (Johnson and Johnson, 1999). It is in this group activity that observation, investigation and decision-making based on a scientific attitude are applied, thereby training their literacy skills. Working on scientific literacy activities for Bio Scientist 1 and other features in developed textbooks can also be viewed as student activities during the learning process.

One of the students' answers in working on the feature bio-scientist in textbooks shows the existence of textbooks that can create meaningful learning, because to write down students' answers they need to conduct scientific investigations. This Bio Scientist feature invites students to carry out an activity that requires scientific work in accordance with the opinions of other researchers, that science is knowledge and a process, so that science textbooks must also provide students with activities that can guide them to work on the scientific process systematically (Elvionita et al., 2019). 
Results:

Thinking literacy: Observing Observations

Table 1. Observation results

\begin{tabular}{||c|c|c|}
\hline \multirow{2}{*}{ No } & \multicolumn{2}{|c|}{ Types of Organism } \\
\cline { 2 - 3 } & Environment with a temperature of $\mathbf{2 9}^{\circ} \mathrm{C}$ & Environment with a temperature of $32^{\circ} \mathrm{C}$ \\
\hline 1. & Grass & Arid terrain \\
\hline 2. & Moss & Grass \\
\hline 3. & Small plant & Ants \\
\hline 4. & Ants & Chicken \\
\hline
\end{tabular}

Thinking literacy: Analyzing information about a phenomenon

1. Are there differences in organisms in wet and dry environments? Yes, there are

Figure 2. The results of students working on questions on one of the textbook features.

2. In your opinion, does temperature and humidity affect the vegetation or the types of living things in your experimental plot? Yes, it does

3. Relate your experiment to the different biomes on the earth's surface! The difference in the temperature of each region of the earth causes different biomes.

4. Predict what will happen if the temperature on earth continues to increase? If the temperature continues to increase, then the ecosystem will be out of balance.

\section{Thinking literacy: Concluding}

5. What conclusions can you draw based on your observations? Temperature and humidity have an impact on Earth's diversity

Figure 3. Continuation of students working on questions on one of the textbook features.

Student responses while using textbooks were also recorded through the results of filling out student response sheets at the end of the lesson. The results of student responses are presented in Table 4.

Table 4. Students' response of textbook based on collaborative learning model.

\begin{tabular}{llcc}
\hline \multicolumn{1}{c}{ Aspect } & \multicolumn{2}{c}{ Percentage of Answer(\%) } \\
\cline { 3 - 4 } & \multicolumn{1}{c}{ Yes } & No \\
\hline A. & Presentation of contents & 100 & 0 \\
\hline 1. & Textbooks are in accordance with learning objectives & 93.3 & 6.7 \\
2. & Textbooks are easy to understand & 93.3 & 6.7 \\
3. & $\begin{array}{l}\text { Textbooks can help students improve cooperation } \\
\text { within the group }\end{array}$ & \multirow{2}{*}{86.7} & 13.3 \\
4extbooks can help boost confidence in the delivery of & & \\
\hline
\end{tabular}




\begin{tabular}{|c|c|c|c|}
\hline & \multirow{2}{*}{ Aspect } & \multicolumn{2}{|c|}{ Percentage of Answer(\%) } \\
\hline & & Yes & No \\
\hline 5. & $\begin{array}{l}\text { Textbooks can help students so that they can carry out } \\
\text { exploration activities }\end{array}$ & 100 & 0 \\
\hline 6. & $\begin{array}{l}\text { Textbooks can improve process skills (observation / } \\
\text { experiment as scientific literacy activities) }\end{array}$ & 100 & 0 \\
\hline 7. & Textbooks may help to think in identifying problems & 100 & 0 \\
\hline 8. & $\begin{array}{l}\text { Textbooks can help students think in assessing a } \\
\text { problem }\end{array}$ & 100 & 0 \\
\hline 9. & Textbooks can help students think in solving a problem & 86.7 & 13.3 \\
\hline 10 & $\begin{array}{l}\text { Textbooks can help students think in expressing } \\
\text { solutions to problem solving }\end{array}$ & 93.3 & 6.7 \\
\hline 11. & $\begin{array}{l}\text { Textbooks help students to be able to predict a scientific } \\
\text { phenomenon }\end{array}$ & 100 & 0 \\
\hline 12. & $\begin{array}{l}\text { Textbooks can add insight to students about the scope of } \\
\text { the ecosystem }\end{array}$ & 100 & 0 \\
\hline B. & Physical Presentation of Books & & \\
\hline 13. & The attractiveness of textbook appearance & 86.7 & 13.3 \\
\hline 14. & $\begin{array}{l}\text { Content/images in textbooks can make students } \\
\text { interested in reading that }\end{array}$ & 93.3 & 6.7 \\
\hline 15. & Features contained in textbooks are interesting & 93.3 & 6.7 \\
\hline 16. & $\begin{array}{l}\text { Textbook illustrations can support understanding } \\
\text { related to material }\end{array}$ & 93.3 & 6.7 \\
\hline C. & Language using in this book & & \\
\hline 19. & The textbook uses polite language & 100 & 0 \\
\hline 20. & $\begin{array}{l}\text { The presentation of the language in the textbook is } \\
\text { interactive }\end{array}$ & 93.3 & 6.7 \\
\hline & Total score & 1899.9 & 100.1 \\
\hline & Average & 95 & 5 \\
\hline
\end{tabular}

Student responses to the physical presentation of books obtained an average percentage of $93.3 \%$. Based on Riduwan (2013), the score interpretation criteria show that the student's response to the physical presentation is "Very positive". However, in the developed textbooks there were $6.7 \%$ of the total 15 respondents who stated that the appearance of the book was less attractive, so that based on the response, it could be used as improvement material for the development of better textbooks. In addition to respondents who stated that the appearance of the book was less attractive, there were also respondents who stated that the textbook was interesting. This is indicated by the response of one of the students in the comment column provided, namely "The book is interesting, easy to understand and has complete contents".

Student responses to the presentation of language obtained a positive response percentage of $95.83 \%$ with a score interpretation of "very positive". As many as $100 \%$ of students stated that the textbook was interactive so that it would be easier to understand the material. The results of student responses give an impression or picture related to the knowledge that students feel and get from learning (Lowery, 2005; Djamarah and Bahri, 2008). The positive response shows that most students have high attention to learning activities using the collaborative learning model. Students' attention to learning activities and learning components is very important for the achievement of learning objectives. This is in accordance with Bandura's statement, that 
learning requires students' interest in something in order to learn optimally (Plass et al., 2010). In addition, textbooks as learning media should attract interest and motivate students to study further, so that they can develop their abilities (Toharudin, 2011). Based on the results of the research above, it is important for educators to practice scientific literacy skills. one of the alternatives provided is by using textbook-based collaborative learning model on ecosystem materials. Further research, related to extensive trials, is expected to be carried out to strengthen the results of the effectiveness of textbooks in training scientific literacy skills. Educators and researchers can also develop textbook-based collaborative learning model on other materials.

\section{CONCLUSIONS}

Textbook-based collaborative learning on ecosystem materials have been shown to improve students' scientific literacy skills. Students showed a positive response to the use of textbooks. As a result, this textbook can be tested widely and become an alternative to practicing scientific literacy skills. Textbook-based collaborative learning model only cover ecosystem material, which is one of the limitations of research that needs to be considered. Teachers as facilitators are expected to provide learning that directs students to scientific literacy and familiarizes them with doing science literacy skills tests according to PISA directions. Further research in the form of implementing learning models, developing learning media and various other alternatives to train students' scientific literacy skills, hopefully can be done.

\section{ACKNOWLEDGEMENTS}

Thank you to Indonesia Endowment Fund for Education (LPDP) from the Ministry of Finance Republic Indonesia for granting the scholarship.

\section{REFERENCES}

Afriana, J., Ismail, \& Rahman, A. A. (2015). Improving scientific literacy through project-based learning. Proceeding of International Seminar on Science Education, 1(1), 234-241.

Al Omoush, K. S. (2018). Web-based collaborative systems and harvesting the collective intelligence in business organizations. International Journal on Semantic Web and Information Systems (IJSWIS) IGI Global, 14(3), 31-52. doi.org/10.4018/IJSWIS.2018070102.

Anfa, Q., Rachmadiarti, F., \& Winarsih. (2016). Kelayakan teoretis lembar kegiatan siswa collaborative-learning materi ekologi untuk melatihkan keterampilan literasi sains siswa kelas X SMA. BioEdu, 5(1), 122-127.

Ansari, J. A. N., \& Khan, N. A. (2020). Exploring the role of social media in collaborative learning the new domain of learning. Smart Learning Environments, 7(1), 9-15. doi.org/10.1186/s40561-020-00118-7

Apriono, D. (2013). Pembelajaran kolaboratif: Suatu landasan untuk membangun kebersamaan dan keterampilan kerjasama. Jurnal Diklus, 17(1), 10-12.

Chen, C. M., \& Kuo, C. H. (2019). An optimized group formation scheme to promote collaborative problem-based learning. Computers and Education, 133(64), 94-115. doi.org/10.1016/j.compedu.2019.01.011

Badan Standar Nasional Pendidikan (BNSP). (2014). Naskah akademik instrumen penilaian buku teks pelajaran dasar dan menengah. Jakarta: BSNP 
Diana, S., Rachmatulloh, A., \& Rahmawati, E. S. (2015). Profil kemampuan literasi sains siswa sma berdasarkan instrumen scientific Literacy Assesments (SLA). Seminar Nasional XII Pendidikan Biologi FKIP UNS 2015, 7(1), 285-291.

Djamarah \& Bahri, S. (2008). Psikologi belajar. Jakarta: Rineka Cipta

Dooley, L. M., \& Bamford, N. J. (2018). Peer feedback on collaborative learning activities in veterinary education. Veterinary Sciences, 5(4), 90-99. doi.org/10.3390/vetsci5040090

Elvionita, S., Ratnawulan, \& Fauzi, A. (2019). Evaluating the validity of integrated science textbook on the theme of tsunami using webbed model based on polya problem solving to enhance students' preparedness toward disaster. Journal of Physics Conference Series, 1185(1), 1-10. doi.org/10.1088/1742-6596/1185/1/012062

Fakomogbon, M. A., \& Bolaji, H. O. (2017). Effects of collaborative learning styles on performance of students in a ubiquitous collaborative mobile learning environment. Contemporary Educational Technology, 8(3), 268-279. doi.org/10.30935/cedtech/6200

Gunawan. (2016). Analisis kesalahan dalam menyelesaikan soal cerita pada mata pelajaran matematika siswa kelas V SDN 59 kota Bengkulu. Jurnal PGSD: Jurnal Ilmiah Pendidikan Guru Sekolah Dasar, 9(2), 216-225. doi.org/10.33369/pgsd.9.2.216225

Hake, R. R. (2014). Design-based research in physics education: A review. Routledge.

Hera, R., Khairil, \& Hasanuddin. (2014). Pengembangan handout pembelajaran embriologi berbasis kontekstual pada perkuliahan perkembangan hewan untuk meningkatkan pemahaman konsep maha peserta didik di Universitas Muhammadiyah Banda Aceh. Jurnal EduBio Tropika, 2(2), 187-250.

Johnson, D. W., \& Johnson, R. T. (1999). Making cooperative learning work. Theory Into Practice, 38(1), 67-73. doi.org/10.1080/00405849909543834

Laal, M., \& Laal, M. (2012). Collaborative learning: What is it?. Procedia-Social and Behavioral Sciences, 31(1), 491-495. doi.org/10.1016/j.sbspro.2011.12.092

Laily, M. N., \& Rachmadiarti, F. (2019). Validitas buku ajar berbasis collaborative learning materi keanekaragaman hayati Kelas $X$ untuk melatihkan keterampilan literasi sains peserta didik. BioEdu, 8(2), 152-161.

Laugksch, R. C. (2017). Scientific literacy: A conceptual overview. John Wiley $\mathcal{E}$ Sons, Inc.in Science Education, 84(1), 70-94. doi.org/10.1002/(SICI)1098237X(200001)84:13.0.CO;2-C

Le, H., Janssen, J., \& Wubbels, T. (2017). Collaborative learning practices: teacher and student perceived obstacles to effective student collaboration. Cambridge Journal of Education, 48(1), 103-122. doi.org/10.1080/0305764x.2016.1259389

Leeuwen, A. V., \& Janssen, J. (2019). A systematic review of teacher guidance during collaborative learning in primary and secondary education. Educational Research Review, 27(1), 71-89. doi.org/10.1016/j.edurev.2019.02.001

Liu, C. H., \& Matthews, R. 2005. Vygotsky's philosophy: Constructivism and its criticisms examined. International Education Journal, 6(3), 386-399.

Lowery, R. C. (2005). Teaching and learning with interactive student response systems: A comparison of commercial products in the higher-education market. Semantic.

Merta, I. A., Artayasa, I. P., Kusmiyati, Lestari, N., \& Setiadi, D. (2020). Profil literasi sains dan model pembelajaran dapat meningkatkan kemampuan literasi sains. Jurnal Pijar MIPA, 15(3), 223-228. doi.org/10.29303/jpm.v15i3.1889 
Millah, E. S., Budipramana, L. S., \& Isnawati. (2012). Pengembangan buku ajar materi bioteknologi di kelas XII SMA IPIEMS Surabaya berorientasi sains, teknologi, lingkungan, dan masyarakat (SETS). Bioedu, 1(1), 19-24.

Plass, J. L., Moreno, R., \& Brunken, R. (2010). Cognitive load theory. Amerika: Cambridge University Press. doi.org/10.1017/CBO9780511844744

Riduwan. (2013). Skala pengukuran variabel-variabel penelitian. Bandung: Alfa Beta.

Robbia, A. Z., \& Fuadi, H. (2015). Pengembangan keterampilan multimedia interaktif pembelajaran ipa untuk meningkatkan literasi sains peserta didik di abad 21 . Jurnal Ilmiah Profesi Pendidikan, 5(2), 117 - 123. doi.org/10.29303/jipp.v5i2.125

Saglam, H. I. (2011). An investigation on teaching materials used in social studies lesson. Turkish Online Journal of Educational Technology-TOJET, 10(1), 36-44.

Saqr, M., Fors, U., \& Tedre, M. (2018). How the study of online collaborative learning can guide teachers and predict students' performance in a medical course. BMC Medical Education, 18(1), 24-30. doi.org/10.1186/s12909-018-1126-1

Saraswati, Y., Indana, S., \& Sudibyo, E. (2021). Science literacy profile of junior high school students based on knowledge, competence, cognitive, and context aspects. IJORER: International Journal of Recent Educational Research, 2(3), 329-34. doi.org/10.46245/ijorer.v2i3.118

Setiadi, D. (2013). Model pembelajaran berbasis peningkatan literasi sains dan implementasinya dalam kurikulum sains SMP 2013. Jurnal Pijar MIPA, 9(1), 1-8.

Siemens, G. (2008). Learning and knowing in networks: Changing roles for educators and designers. ITFORUM Discuss, 27(1), 1-26.

Sugiyono. (2011). Metode penelitian pendidikan. Bandung: Alfabeta

Suryani, D. \& Hariyono,E. (2021). Geoscience Literacy Profile of Junior High School Students. IJORER: International Journal of Recent Educational Research, 2(3), 305-315. https://doi.org/10.46245/ijorer.v2i3.105

Susanto, A. (2013). Teori belajar dan pembelajaran di sekolah dasar. Jakarta: Kencana Prenadamedia Group

Toharudin, U. (2011). Membangun literasi sains peserta didik. Bandung: humaniora.

Voorn, R. J., \& Kommers, P. A. (2013). Social media and higher education: Introversion and collaborative learning from the student's perspective. International Journal of Social Media and Interactive Learning Environments, 1(1), 59-73. doi.org/10.1504/IJSMILE.2013.051650

Weinberger, A., Stegmann, K., \& Fischer, F. (2007). Knowledge convergence in collaborative learning: Concept and assessment. Learning and Instruction, 17(1), 416-426. doi.org/10.1016/j.learninstruc.2007.03.007

Zhang, Q., Voogt, J., \& Akker, J.V.D. (2013). A Professional development arrangement for supporting teachers' enacting inquiry-based integrative practical activities in China. Educational Design Research - Part B: Illustrative Cases, 3(1), 487-510.

\footnotetext{
*Virlya Citra Dewi (Corresponding Author)

Postgraduate program, Science Education

Universitas Negeri Surabaya

Jl. Lidah Wetan, Surabaya, East Java, Indonesia

Email: virlya.19013@mhs.unesa.ac.id
} 


\section{Prof. Dr. Endang Susantini, M.Pd.}

Postgraduate program, Science Education

Universitas Negeri Surabaya

Jl. Lidah Wetan, Surabaya, East Java, Indonesia

Email: endangsusantini@unesa.ac.id

\section{Prof. Dr. Sri Poedjiastoeti, M.Si}

Postgraduate program, Science Education

Universitas Negeri Surabaya

Jl. Lidah Wetan, Surabaya, East Java, Indonesia

Email: sripoedjiastoeti@yahoo.com 